\title{
Angiogenesis, Cancer, and Vascular Aging
}

\author{
Junji Moriya ${ }^{1}$ and Tohru Minamino ${ }^{2 *}$ \\ ${ }^{1}$ Office of Cellular and Tissue-Based Products, Pharmaceuticals and Medical Devices Agency, Tokyo, Japan, ${ }^{2}$ Department of \\ Cardiovascular Biology and Medicine, Niigata University Graduate School of Medical and Dental Sciences, Niigata, Japan
}

\section{OPEN ACCESS}

Edited by:

Antonio Paolo Beltrami,

University of Udine, Italy

Reviewed by:

Lucio Barile,

Cardiocentro Ticino Foundation,

Switzerland

Sarah Costantino,

University of Zurich, Switzerland

*Correspondence:

Tohru Minamino

tminamino@med.niigata-u.ac.jp,

t_minamino@yahoo.co.jp

Specialty section:

This article was submitted to

Cardiovascular Biologics and

Regenerative Medicine,

a section of the journal

Frontiers in Cardiovascular Medicine

Received: 09 August 2017 Accepted: 09 October 2017

Published: 24 October 2017

Citation:

Moriya J and Minamino T (2017)

Angiogenesis, Cancer,

and Vascular Aging.

Front. Cardiovasc. Med. 4:65.

doi: 10.3389/fcvm.2017.00065
Several lines of evidence have revealed that the angiogenic response to ischemic injury declines with age, which might account for the increased morbidity and mortality of cardiovascular disease (CVD) among the elderly. While impairment of angiogenesis with aging leads to delayed wound healing or exacerbation of atherosclerotic ischemic diseases, it also inhibits the progression of cancer. Age-related changes of angiogenesis have been considered to at least partly result from vascular aging or endothelial cell senescence. There is considerable evidence supporting the hypothesis that vascular cell senescence contributes to the pathogenesis of age-related CVD, suggesting that vascular aging could be an important therapeutic target. Since therapeutic angiogenesis is now regarded as a promising concept for patients with ischemic CVD, it has become even more important to understand the detailed molecular mechanisms underlying impairment of angiogenesis in older patients. To improve the usefulness of therapeutic angiogenesis, approaches are needed that can compensate for impaired angiogenic capacity in the elderly while not promoting the development or progression of malignancy. In this review, we briefly outline the mechanisms of angiogenesis and vascular aging, followed by a description of how vascular aging leads to impairment of angiogenesis. We also examine potential therapeutic approaches that could enhance angiogenesis and/or vascular function in the elderly, as well as discussing the possibility of antisenescence therapy or reversal of endothelial cell senescence.

Keywords: aging, therapeutic angiogenesis, cellular senescence, angiogenic factors, endothelial progenitor cells, cancer

\section{INTRODUCTION}

There is accumulating evidence that angiogenesis, which is the process of forming new blood vessels from existing vascular structures, declines significantly with aging (1-6). Aging is a major risk factor for various diseases. In the United States, people over 65 years old have a higher prevalence of cardiovascular disease (CVD), and the prevalence of CVD will increase by nearly $10 \%$ over the next two decades (7). Age-dependent impairment of angiogenesis is considered to be one of the main contributors to increased cardiovascular morbidity and mortality. Therefore, understanding the mechanisms by which aging induces pathophysiological changes of the vascular system, including impairment of angiogenesis, is critical for developing therapeutic strategies to manage age-related CVD. This review outlines the mechanisms of angiogenesis and vascular aging or endothelial cell senescence. Then recent evidence for the association between vascular aging and angiogenesis is 
described, followed by discussion about the potential to develop therapeutic angiogenesis and anti-senescence therapy for agerelated CVD.

\section{ANGIOGENESIS IN THE ELDERLY}

\section{Major Mechanisms of Neovascularization}

Growth of new blood vessels in response to certain stimuli such as tissue ischemia is called neovascularization and is categorized into three mechanisms, which are angiogenesis, arteriogenesis, and vasculogenesis (8). Angiogenesis occurs in small capillaries and involves sprouting of existing vascular endothelial cells (9). Arteriogenesis is a mechanism by which larger arteries form collateral vessels to maintain the blood supply after occlusion (10), while vasculogenesis involves the creation of vessels mainly by endothelial progenitor cells (EPCs), which were first reported in 1997 (11). The putative EPCs were initially typified by expression of CD34 and vascular endothelial growth factor receptor-2 (VEGFR-2) (11), then specified by additional various other markers expressed on their surface, such as CD 133, CD31, and von Willebrand factor $(12,13)$. It is known that EPCs arise from the bone marrow and differentiate into endothelial cells which form de novo vascular structures $(8,14)$. All three mechanisms are believed to contribute to the development of physiological or pathological neovascularization.

\section{Effects of Aging on Angiogenesis}

Recovery of blood flow after hind limb ischemia is reported to be impaired in older animals compared with young animals (1). Consistent with this finding, the development of collateral arteries is significantly impaired in older patients with coronary artery disease (15), and the incidence of amputation is high in elderly patients with acute lower limb ischemia (16). These observations support the notion that impairment of angiogenesis occurs with aging. Indeed, endothelial cells from aged mice show a decreased capacity for both proliferation and migration $(2,3)$. Moreover, impairment of angiogenesis with aging contributes to delayed wound healing. Healing of skin wounds is a process that involves aggregation of keratinocytes and fibroblasts through the formation of highly vascular granulation tissue $(2,17,18)$. Many aspects of the healing process are influenced by aging, and it was reported that formation of benign granulomas is inhibited in aged mice along with a decrease of capillary density (2).

On the other hand, progression of cancer is generally slower in the elderly compared with younger patients, although the incidence of cancer increases with age. In addition to the reduced capacity of tumor cells for proliferation and migration, impairment of angiogenesis is considered to have an important role in slowing the growth of cancer in elderly patients (19). Angiogenesis is essential for tumor progression, and there is an association between tumor vascularity and the prognosis of most neoplasms. In aged mice, invasion of malignancies is suppressed along with a decrease of tumor vasculature (19), and a reduced tumor microvessel count was reported in elderly patients with breast cancer (20). Thus, impairment of angiogenesis in the elderly is likely to have an influence on the prognosis of cancer, and attenuation of angiogenic capacity with aging can be seen as a mechanism that inhibits tumor progression.

\section{MOLECULAR MECHANISMS OF VASCULAR AGING}

The age-related reduction of angiogenic capacity and endothelial function is believed to at least partly stem from a phenomenon called vascular aging (21), which is characterized by cellular senescence affecting the vascular endothelium. In cultured cells, cellular senescence is the term for irreversible growth arrest that occurs after a certain number of cell division cycles (22). Senescent cells exhibit both morphological changes and phenotypic alterations associated with differences of gene expression (23). It is known that the lifespan of cultured cells is negatively correlated with the age of the donor, and that primary cultured cells from patients with premature aging syndromes have a significantly shorter lifespan $(24,25)$. These observations have led to the hypothesis that cellular senescence is associated with the aging processes, which was first postulated in the 1960s $(26,27)$. This hypothesis has been extensively investigated during the past few decades, leading to improved understanding of the molecular mechanisms underlying cellular senescence. The biological significance of cellular senescence is recognized to be its role as a protective mechanism against carcinogenesis due to DNA damage or various cellular stresses $(28,29)$. However, a recent study revealed that anti-inflammatory therapy with canakinumab could significantly reduce incident lung cancer in patients with atherosclerosis (30). Because aging is known to promote vascular inflammation by increasing reactive oxygen species (ROS) production (6), chronic inflammation during vascular aging might promote progression of cancer.

One of the most widely discussed hypotheses that could explain vascular cell senescence is the telomere hypothesis (31). Telomeres are chromatin complexes composed of non-nucleosomal DNA (TTAGGG repeats) and various telomere-binding proteins that are located at the ends of chromosomes and contribute to genomic stability by protecting this region from degradation and recombination (32). Telomeres become shorter with each cell division, possibly due to imperfect duplication of the extreme terminals of the chromosomes by DNA polymerase. Progressive telomere shortening eventually triggers senescence and reduces the proliferative capacity of cells (33). Telomerase is an enzyme that elongates telomeres by using its RNA component as a template (34). Introduction of telomerase into human endothelial cells inhibits telomere shortening with cell division and protect against senescence, suggesting that telomeres may have an important role in vascular cell senescence (35-37).

In addition to the telomere hypothesis, some telomereindependent mechanisms of vascular aging have been suggested. Angiotensin II induces premature senescence of human vascular smooth muscle cells without affecting telomere length by upregulating p53/p21 expression and activating nuclear factor kappa B to increase proinflammatory cytokine production (38). Senescence of human vascular endothelial cells was also reported to involve activation of Akt, suggesting that insulin/Akt signaling may 
be important in regulating the lifespan of these cells (39). This mechanism is reported to be related to control of the production of $\operatorname{ROS}(39)$.

\section{MECHANISM OF IMPAIRED ANGIOGENESIS ASSOCIATED WITH VASCULAR AGING}

Several mechanisms have been proposed as potential underlying causes of the age-related impairment of angiogenesis.

\section{Reduced Production/Response to Growth Factors and Nitric Oxide (NO)}

It is known that expression of vascular growth factors and/or the response to these factors is attenuated in elderly persons. Production of vascular endothelial growth factor (VEGF), which is one of the key regulators of physiological and pathological angiogenesis (40-42), is decreased in the elderly at both basal levels and in response tissue injury (43-45). This is thought to be due to reduced activation of hypoxia-inducible factor- $1 \alpha$, a transcription factor for VEGF $(46,47)$. Also, expression of platelet-derived growth factor is inhibited in cardiac endothelial cells from aged rats (48), while the response of senescent human umbilical vein endothelial cells to basic fibroblast growth factor (FGF) is diminished due to impaired tyrosine phosphorylation of FGF receptors (49). All of these changes are likely to contribute to impairment of angiogenesis in the elderly.

Moreover, production of $\mathrm{NO}$ is decreased in the vascular cells of elderly persons or in senescent endothelial cells (50-52). Reduced bioavailability of NO with aging not only inhibits vasodilation through its innate effect, but also increases the sensitivity of endothelial cells to apoptotic stimuli, leading to disruption of endothelial function and angiogenic potential (53).

\section{Reduced Number/Function of EPCs}

Endothelial progenitor cells are cells recruited from the bone marrow to sites of ischemia that promote neovascularization by undergoing differentiation into endothelial cells $(11,54)$. EPCs are currently utilized for therapeutic angiogenesis as a form of cell transplantation therapy (55-57). EPCs obtained from elderly persons show reduced survival, migration, and proliferation in culture, suggesting functional impairment due to cellular senescence (58). Interestingly, the number and function of EPCs are inversely correlated with various risk factors for atherosclerosis (59-61). Exhaustion of these cells not only leads to impaired angiogenesis but also attenuates the maintenance of vascular homeostasis, which might result in initiation of atherosclerosis (62). Indeed, EPCs from patients with coronary artery disease show reduced proliferation and migration, while EPC numbers are decreased in patients with advanced coronary artery stenosis (63-65). The decline of EPC numbers is considered to result from impairment of differentiation in the bone marrow with aging, as well as attenuated recruitment of these cells due to reduced VEGF production in peripheral tissues. These changes could be partially explained by age-related alterations of the stem cell niche, such as decreased tenascin-C expression in bone marrow (66).

\section{Changes of the Extracellular Matrix}

Endothelial cell proliferation requires a scaffold for cells to migrate and space for cells to grow, created by degradation of the basement membrane around blood vessels. Correct organization of the extracellular matrix has a critical influence on this process $(67,68)$. Because production of extracellular proteins such as fibronectin and collagen is known to decrease with aging, this change has been suggested to make a contribution to impairment of angiogenesis $(69,70)$.

Matrix metalloproteinases (MMPs) are proteases involved in degradation of the extracellular matrix (71). MMPs can be divided into several groups on the basis of cellular localization, biochemical properties, and sequence similarities (Table 1) (71). As well as production of extracellular proteins, the activity of MMPs decreases with aging (72). Conversely, the expression of tissue inhibitor of metalloproteinase, which inhibits MMPs, is enhanced by aging (73). The resulting dysregulation of MMPs is considered to be one of the key factors leading to impairment of angiogenesis in elderly persons, along with increased production of angiogenic inhibitors such as thrombospondins $(3,74,75)$.

\section{Cellular Senescence}

Cellular senescence is believed to result from telomere shortening associated with successive cell division and chronic oxidative stress (76). Several studies have demonstrated that atherosclerotic lesions contain senescent vascular endothelial cells (77-79), and the telomere length of somatic cells is inversely correlated with the number of risk factors for atherosclerosis (80-86). In addition to the decline of replicative capacity, cellular senescence leads to increased expression of inflammatory cytokines and decreased production of NO by the vascular endothelium $(87,88)$. These changes associated with aging are considered to play a key role

TABLE 1 | Matrix metalloproteinase (MMP) family.

\begin{tabular}{|c|c|}
\hline Enzyme & MMP \\
\hline \multicolumn{2}{|l|}{ I. Collagenase group } \\
\hline Interstitial collagenase (collagenase-1) & MMP-1 \\
\hline Neutrophil collagenase (collagenase-2) & MMP-8 \\
\hline Collagenase-3 & MMP-13 \\
\hline \multicolumn{2}{|l|}{ II. Gelatinase group } \\
\hline Gelatinase A & MMP-2 \\
\hline Gelatinase B & MMP-9 \\
\hline \multicolumn{2}{|l|}{ III. Stromelysins } \\
\hline Stromelysin-1 & MMP-3 \\
\hline Stromelysin-2 & MMP-10 \\
\hline Stromelysin-3 & MMP-11 \\
\hline \multicolumn{2}{|l|}{ IV. Membrane-type (MT) MMPs } \\
\hline MT-1 MMP & MMP-14 \\
\hline MT-2 MMP & MMP-15 \\
\hline MT-3 MMP & MMP-16 \\
\hline MT-4 MMP & MMP-17 \\
\hline MT-5 MMP & MMP-24 \\
\hline MT-6 MMP & MMP-25 \\
\hline \multicolumn{2}{|l|}{ v. Others } \\
\hline Matrilysin & MMP-7 \\
\hline Macrophage elastase (metalloelastase) & MMP-12 \\
\hline Enamelysin & MMP-20 \\
\hline Other human metalloproteases & MMP-18, MMP-19, MMP-23 \\
\hline
\end{tabular}


in the development of atherosclerosis, as well as directly leading to impairment of angiogenesis (22). EPCs also develop the functional and phenotypic characteristics of cellular senescence in elderly persons, resulting in impaired functioning of these cells $(21,58,89)$.

\section{THERAPEUTIC IMPLICATIONS OF AGE-RELATED IMPAIRMENT OF ANGIOGENESIS}

Atherosclerotic ischemic diseases, such as arteriosclerosis obliterans and ischemic heart disease, are among the major age-related diseases with surging morbidity and mortality (90). Atherosclerotic plaques from older patients tend to be larger with significant stenosis, as well as having more calcified lesions (91). Angiogenesis is promptly triggered by ischemia, but this response is attenuated in the elderly $(1,2,5)$. While revascularization is currently the most effective treatment for ischemia, many patients are unsuitable for this therapy due to technical reasons or unclear benefit, especially among the elderly population (92). Wound healing is also impaired with aging, and this change is associated with reduced levels of angiogenic factors such as VEGF or FGF $(2,4)$.

Previous preclinical studies and small-scale clinical trials have shown that gene therapy or the delivery of VEGF or FGF protein, as well as cell therapy employing EPCs and bone marrow or peripheral blood mononuclear cells, have some efficacy for alleviating ischemia. These revascularization strategies are collectively called therapeutic angiogenesis (93-96). Moreover, local application of basic FGF to refractory skin ulcers has been shown to promote wound healing and has demonstrated remarkable clinical benefit (97-99), leading to approval of basic FGF as a topical treatment in Japan.
Unfortunately, therapeutic angiogenesis is not always effective. Among patients with critical limb ischemia, nearly half of those treated do not achieve sufficient improvement of ischemic symptoms (100). The key reasons for lack of improvement are considered to be an attenuated response to growth factors and decreased viability or function of transplanted cells due to cellular senescence (5). One of the potential strategies to overcome these problems is modification of senescenceassociated molecules. Indeed, it has been reported that transduction of the human telomerase reverse transcriptase (TERT) gene into EPCs led to improvement of neovascularization in a murine model of hind limb ischemia (101), with this explicit anti-senescence strategy serving as a model for therapeutic angiogenesis.

However, it should be noted that both cellular senescence and impairment of angiogenesis are mechanisms inhibiting cancer progression $(4,23)$. Strategies such as introduction of the TERT gene, as mentioned above, are thought to be associated with a high risk of cancer (101), and clinical application of this technology would be difficult in its present form. Thus, employing therapeutic angiogenesis in elderly patients will always be associated with a certain risk of promoting the development of cancer. Because therapeutic angiogenesis or anti-senescence therapy for the elderly is a two-edged sword, it is important to focus on therapeutic targets that are as specific as possible (Figure 1). Accordingly, local administration of these therapies could be one option. Additionally, various drugs with known cardioprotective effects, such as statins (102), thiazolidinediones (103), aspirins (104), and estrogens (105), have also been reported to increase telomerase activity and are not considered to increase the risk of malignancy. Thus, targeting the appropriate senescenceassociated molecules may allow development of safe and effective anti-senescence therapy.

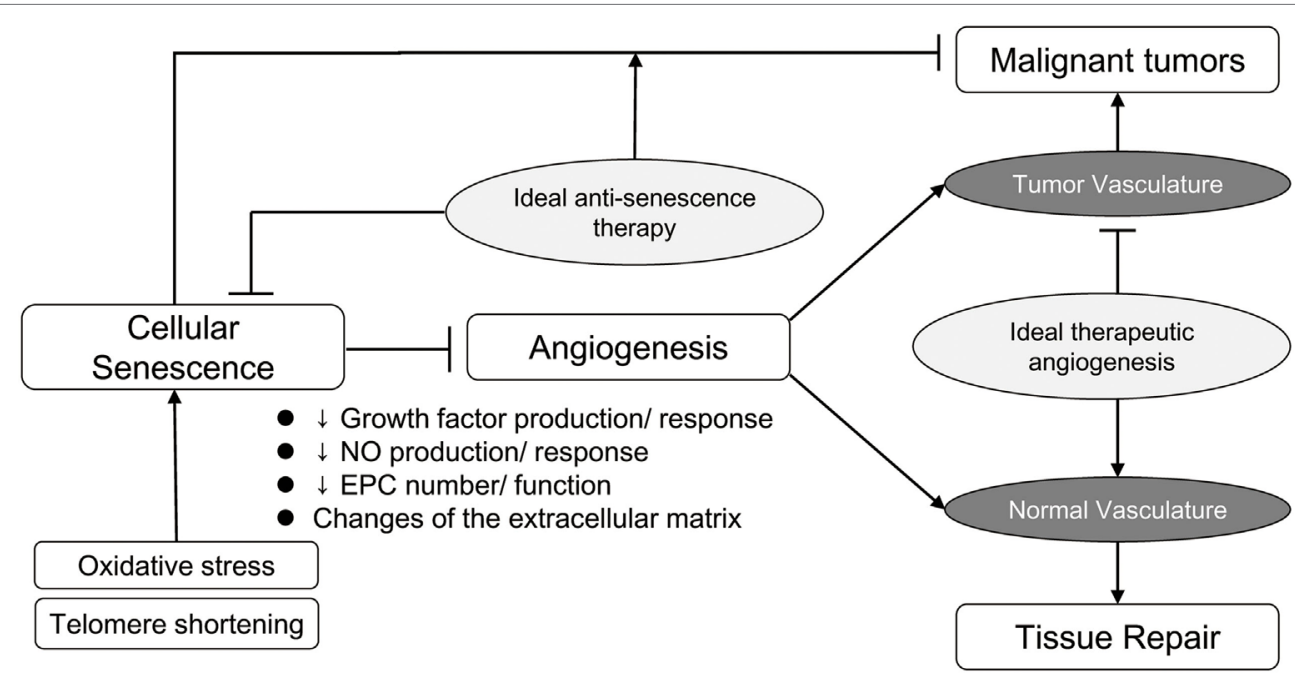

FIGURE 1 | Ideal antisenescence therapy and therapeutic angiogenesis. Although cellular senescence and impaired angiogenesis have undesirable effects, these age-related changes also inhibit the progression of cancer. Restoring the repair potential of normal tissues, while preserving the protective effect against development and progression of malignant tumors, is the ultimate objective of anti-senescence therapy and therapeutic angiogenesis. 


\section{CONCLUSION}

Although impairment of angiogenesis with aging is detrimental for various ischemic diseases, it conversely has a favorable effect by suppressing the development and progression of malignant tumors. Deeper understanding of the detailed mechanisms involved in vascular aging and angiogenesis may lead to ideal molecular-targeted therapy that promotes angiogenesis by suppressing age-related signaling pathways while preserving the protective effect against cancer.

\section{AUTHOR CONTRIBUTIONS}

JM wrote the manuscript and TM revised the manuscript.

\section{REFERENCES}

1. Rivard A, Fabre JE, Silver M, Chen D, Murohara T, Kearney M, et al. Agedependent impairment of angiogenesis. Circulation (1999) 99(1):111-20. doi:10.1161/01.CIR.99.1.111

2. Swift ME, Kleinman HK, DiPietro LA. Impaired wound repair and delayed angiogenesis in aged mice. Lab Invest (1999) 79(12):1479-87.

3. Sadoun E, Reed MJ. Impaired angiogenesis in aging is associated with alterations in vessel density, matrix composition, inflammatory response, and growth factor expression. J Histochem Cytochem (2003) 51(9):1119-30. doi: $10.1177 / 002215540305100902$

4. Reed MJ, Edelberg JM. Impaired angiogenesis in the aged. Sci Aging Knowledge Environ (2004) 2004(7):e7. doi:10.1126/sageke.2004.7.pe7

5. Lahteenvuo J, Rosenzweig A. Effects of aging on angiogenesis. Circ Res (2012) 110(9):1252-64. doi:10.1161/CIRCRESAHA.111.246116

6. Paneni F, Diaz Canestro C, Libby P, Luscher TF, Camici GG. The aging cardiovascular system: understanding it at the cellular and clinical levels. J Am Coll Cardiol (2017) 69(15):1952-67. doi:10.1016/j.jacc.2017.01.064

7. Heidenreich PA, Trogdon JG, Khavjou OA, Butler J, Dracup K, Ezekowitz MD, et al. Forecasting the future of cardiovascular disease in the United States: a policy statement from the American Heart Association. Circulation (2011) 123(8):933-44. doi:10.1161/CIR.0b013e31820a55f5

8. Tateno K, Minamino T, Moriya J, Katada A, Yokoyama M, Miura K, et al. Cell therapy for cardiovascular diseases. Ann Vasc Dis (2008) 1(2):66-79. doi:10.3400/avd.AVDsr00108

9. Carmeliet P. Angiogenesis in health and disease. Nat Med (2003) 9(6):653-60. doi:10.1038/nm0603-653

10. Scholz D, Cai WJ, Schaper W. Arteriogenesis, a new concept of vascular adaptation in occlusive disease. Angiogenesis (2001) 4(4):247-57. doi:10.1023/ A:1016094004084

11. Asahara T, Murohara T, Sullivan A, Silver M, van der Zee R, Li T, et al. Isolation of putative progenitor endothelial cells for angiogenesis. Science (1997) 275(5302):964-6. doi:10.1126/science.275.5302.964

12. Hirschi KK, Ingram DA, Yoder MC. Assessing identity, phenotype, and fate of endothelial progenitor cells. Arterioscler Thromb Vasc Biol (2008) 28(9):1584-95. doi:10.1161/ATVBAHA.107.155960

13. Yoder MC. Human endothelial progenitor cells. Cold Spring Harb Perspect Med (2012) 2(7):a006692. doi:10.1101/cshperspect.a006692

14. Jin SW, Patterson C. The opening act: vasculogenesis and the origins of circulation. Arterioscler Thromb Vasc Biol (2009) 29(5):623-9. doi:10.1161/ ATVBAHA.107.161539

15. Nakae I, Fujita M, Miwa K, Hasegawa K, Kihara Y, Nohara R, et al. Agedependent impairment of coronary collateral development in humans. Heart Vessels (2000) 15(4):176-80. doi:10.1007/PL00007269

16. Ouriel K, Veith FJ. Acute lower limb ischemia: determinants of outcome. Surgery (1998) 124(2):336-41; discussion 41-2. doi:10.1016/ S0039-6060(98)70139-4

17. Ondrovics M, Hoelbl-Kovacic A, Fux DA. Opioids: modulators of angiogenesis in wound healing and cancer. Oncotarget (2017) 8(15):25783-96. doi:10.18632/oncotarget.15419

\section{FUNDING}

This work was supported by a Grant-in-Aid for Scientific Research (grant number 17H04172, 25870127), a Grant-in-Aid for Scientific Research on Innovative Areas (grant number 26115008), and a Grant-in-Aid for Exploratory Research from the Ministry of Education, Culture, Sports, Science and Technology (MEXT, Grant number 15K15306) of Japan and grants from the Takeda Medical Research Foundation, the Japan Foundation for Applied Enzymology, the Takeda Science Foundation, the SENSHIN Medical Research Foundation, the Terumo Foundation, the Manpei Suzuki Diabetes Foundation, the Naito Foundation, and the NOVARITIS foundation (to TM).

18. DiPietro LA. Angiogenesis and scar formation in healing wounds. Curr Opin Rheumatol (2013) 25(1):87-91. doi:10.1097/BOR.0b013e32835b13b6

19. Pili R, Guo Y, Chang J, Nakanishi H, Martin GR, Passaniti A. Altered angiogenesis underlying age-dependent changes in tumor growth. J Natl Cancer Inst (1994) 86(17):1303-14. doi:10.1093/jnci/86.17.1303

20. Marinho A, Soares R, Ferro J, Lacerda M, Schmitt FC. Angiogenesis in breast cancer is related to age but not to other prognostic parameters. Pathol Res Pract (1997) 193(4):267-73. doi:10.1016/s0344-0338(97)80003-9

21. Ungvari Z, Kaley G, de Cabo R, Sonntag WE, Csiszar A. Mechanisms of vascular aging: new perspectives. J Gerontol A Biol Sci Med Sci (2010) 65(10):1028-41. doi:10.1093/gerona/glq113

22. Erusalimsky JD. Vascular endothelial senescence: from mechanisms to pathophysiology. J Appl Physiol (1985) (2009) 106(1):326-32. doi:10.1152/ japplphysiol.91353.2008

23. Minamino T, Komuro I. Vascular cell senescence: contribution to atherosclerosis. Circ Res (2007) 100(1):15-26. doi:10.1161/01.RES.0000256837.40544.4a

24. Thompson KV, Holliday R. Genetic effects on the longevity of cultured human fibroblasts. II. DNA repair deficient syndromes. Gerontology (1983) 29(2):83-8. doi:10.1159/000213097

25. Martin GM. Genetic modulation of senescent phenotypes in Homo sapiens. Cell (2005) 120(4):523-32. doi:10.1016/j.cell.2005.01.031

26. Hayflick L, Moorhead PS. The serial cultivation of human diploid cell strains. Exp Cell Res (1961) 25:585-621. doi:10.1016/0014-4827(61)90192-6

27. Hayflick L. The limited in vitro lifetime of human diploid cell strains. Exp Cell Res (1965) 37:614-36. doi:10.1016/0014-4827(65)90211-9

28. Serrano M, Blasco MA. Putting the stress on senescence. Curr Opin Cell Biol (2001) 13(6):748-53. doi:10.1016/S0955-0674(00)00278-7

29. Lombard DB, Chua KF, Mostoslavsky R, Franco S, Gostissa M, Alt FW. DNA repair, genome stability, and aging. Cell (2005) 120(4):497-512. doi:10.1016/j. cell.2005.01.028

30. Ridker PM, MacFadyen JG, Thuren T, Everett BM, Libby P, Glynn RJ, et al. Effect of interleukin-1 $\beta$ inhibition with canakinumab on incident lung cancer in patients with atherosclerosis: exploratory results from a randomised, double-blind, placebo-controlled trial. Lancet (2017). doi:10.1016/ s0140-6736(17)32247-x

31. Campisi J, Kim SH, Lim CS, Rubio M. Cellular senescence, cancer and aging: the telomere connection. Exp Gerontol (2001) 36(10):1619-37. doi:10.1016/ S0531-5565(01)00160-7

32. Greider CW. Telomere length regulation. Annu Rev Biochem (1996) 65:337-65. doi:10.1146/annurev.bi.65.070196.002005

33. Fuster JJ, Andres V. Telomere biology and cardiovascular disease. Circ Res (2006) 99(11):1167-80. doi:10.1161/01.RES.0000251281.00845.18

34. Blasco MA. Telomeres and human disease: ageing, cancer and beyond. Nat Rev Genet (2005) 6(8):611-22. doi:10.1038/nrg1656

35. Minamino T, Mitsialis SA, Kourembanas S. Hypoxia extends the life span of vascular smooth muscle cells through telomerase activation. Mol Cell Biol (2001) 21(10):3336-42. doi:10.1128/MCB.21.10.3336-3342.2001

36. Yang J, Chang E, Cherry AM, Bangs CD, Oei Y, Bodnar A, et al. Human endothelial cell life extension by telomerase expression. J Biol Chem (1999) 274(37):26141-8. doi:10.1074/jbc.274.37.26141 
37. Chang E, Harley CB. Telomere length and replicative aging in human vascular tissues. Proc Natl Acad Sci U S A (1995) 92(24):11190-4. doi:10.1073/ pnas.92.24.11190

38. Kunieda T, Minamino T, Nishi J, Tateno K, Oyama T, Katsuno T, et al. Angiotensin II induces premature senescence of vascular smooth muscle cells and accelerates the development of atherosclerosis via a p21-dependent pathway. Circulation (2006) 114(9):953-60. doi:10.1161/ CIRCULATIONAHA.106.626606

39. Miyauchi H, Minamino T, Tateno K, Kunieda T, Toko H, Komuro I. Akt negatively regulates the in vitro lifespan of human endothelial cells via a p53/p21-dependent pathway. EMBO J (2004) 23(1):212-20. doi:10.1038/ sj.emboj.7600045

40. Ferrara N, Gerber HP, LeCouter J. The biology of VEGF and its receptors. Nat Med (2003) 9(6):669-76. doi:10.1038/nm0603-669

41. Eichmann A, Simons M. VEGF signaling inside vascular endothelial cells and beyond. Curr Opin Cell Biol (2012) 24(2):188-93. doi:10.1016/j. ceb.2012.02.002

42. Ferrara N. VEGF-A: a critical regulator of blood vessel growth. Eur Cytokine Netw (2009) 20(4):158-63. doi:10.1684/ecn.2009.0170

43. Wagatsuma A. Effect of aging on expression of angiogenesis-related factors in mouse skeletal muscle. Exp Gerontol (2006) 41(1):49-54. doi:10.1016/j. exger.2005.10.003

44. Ryan NA, Zwetsloot KA, Westerkamp LM, Hickner RC, Pofahl WE, Gavin TP. Lower skeletal muscle capillarization and VEGF expression in aged vs. young men. JAppl Physiol (1985) (2006) 100(1):178-85. doi:10.1152/ japplphysiol.00827.2005

45. Croley AN, Zwetsloot KA, Westerkamp LM, Ryan NA, Pendergast AM, Hickner RC, et al. Lower capillarization, VEGF protein, and VEGF mRNA response to acute exercise in the vastus lateralis muscle of aged vs. young women. J Appl Physiol (1985) (2005) 99(5):1872-9. doi:10.1152/ japplphysiol.00498.2005

46. Rivard A, Berthou-Soulie L, Principe N, Kearney M, Curry C, Branellec D, et al. Age-dependent defect in vascular endothelial growth factor expression is associated with reduced hypoxia-inducible factor 1 activity. J Biol Chem (2000) 275(38):29643-7. doi:10.1074/jbc.M001029200

47. Ahluwalia A, Narula J, Jones MK, Deng X, Tarnawski AS. Impaired angiogenesis in aging myocardial microvascular endothelial cells is associated with reduced importin alpha and decreased nuclear transport of HIF1 alpha: mechanistic implications. J Physiol Pharmacol (2010) 61(2):133-9.

48. Xaymardan M, Zheng J, Duignan I, Chin A, Holm JM, Ballard VL, et al. Senescent impairment in synergistic cytokine pathways that provide rapid cardioprotection in the rat heart. J Exp Med (2004) 199(6):797-804. doi:10.1084/jem.20031639

49. Garfinkel S, Hu X, Prudovsky IA, McMahon GA, Kapnik EM, McDowell SD, et al. FGF-1-dependent proliferative and migratory responses are impaired in senescent human umbilical vein endothelial cells and correlate with the inability to signal tyrosine phosphorylation of fibroblast growth factor receptor-1 substrates. J Cell Biol (1996) 134(3):783-91. doi:10.1083/jcb.134.3.783

50. Tschudi MR, Barton M, Bersinger NA, Moreau P, Cosentino F, Noll G, et al. Effect of age on kinetics of nitric oxide release in rat aorta and pulmonary artery. J Clin Invest (1996) 98(4):899-905. doi:10.1172/JCI118872

51. Barton M, Cosentino F, Brandes RP, Moreau P, Shaw S, Luscher TF. Anatomic heterogeneity of vascular aging: role of nitric oxide and endothelin. Hypertension (1997) 30(4):817-24. doi:10.1161/01.HYP.30.4.817

52. Yoon HJ, Cho SW, Ahn BW, Yang SY. Alterations in the activity and expression of endothelial NO synthase in aged human endothelial cells. Mech Ageing Dev (2010) 131(2):119-23. doi:10.1016/j.mad.2009.12.010

53. Papapetropoulos A, Garcia-Cardena G, Madri JA, Sessa WC. Nitric oxide production contributes to the angiogenic properties of vascular endothelial growth factor in human endothelial cells. J Clin Invest (1997) 100(12):3131-9. doi:10.1172/JCI1 19868

54. Asahara T, Masuda H, Takahashi T, Kalka C, Pastore C, Silver M, et al. Bone marrow origin of endothelial progenitor cells responsible for postnatal vasculogenesis in physiological and pathological neovascularization. Circ Res (1999) 85(3):221-8. doi:10.1161/01.RES.85.3.221

55. Kalka C, Masuda H, Takahashi T, Kalka-Moll WM, Silver M, Kearney M, et al. Transplantation of ex vivo expanded endothelial progenitor cells for therapeutic neovascularization. Proc Natl Acad Sci US A (2000) 97(7):3422-7. doi:10.1073/pnas.070046397
56. Kawamoto A, Gwon HC, Iwaguro H, Yamaguchi JI, Uchida S, Masuda H, et al. Therapeutic potential of ex vivo expanded endothelial progenitor cells for myocardial ischemia. Circulation (2001) 103(5):634-7. doi:10.1161/01. CIR.103.5.634

57. Iwasaki H, Kawamoto A, Ishikawa M, Oyamada A, Nakamori S, Nishimura H, et al. Dose-dependent contribution of CD34-positive cell transplantation to concurrent vasculogenesis and cardiomyogenesis for functional regenerative recovery after myocardial infarction. Circulation (2006) 113(10):1311-25. doi:10.1161/CIRCULATIONAHA.105.541268

58. Heiss C, Keymel S, Niesler U, Ziemann J, Kelm M, Kalka C. Impaired progenitor cell activity in age-related endothelial dysfunction. J Am Coll Cardiol (2005) 45(9):1441-8. doi:10.1016/j.jacc.2004.12.074

59. Vasa M, Fichtlscherer S, Aicher A, Adler K, Urbich C, Martin H, et al. Number and migratory activity of circulating endothelial progenitor cells inversely correlate with risk factors for coronary artery disease. Circ Res (2001) 89(1):E1-7. doi:10.1161/hh1301.093953

60. Tepper OM, Galiano RD, Capla JM, Kalka C, Gagne PJ, Jacobowitz GR, et al. Human endothelial progenitor cells from type II diabetics exhibit impaired proliferation, adhesion, and incorporation into vascular structures. Circulation (2002) 106(22):2781-6. doi:10.1161/01.CIR.0000039526.42991.93

61. Hill JM, Zalos G, Halcox JP, Schenke WH, Waclawiw MA, Quyyumi AA, et al. Circulating endothelial progenitor cells, vascular function, and cardiovascular risk. N Engl J Med (2003) 348(7):593-600. doi:10.1056/NEJMoa022287

62. Rauscher FM, Goldschmidt-Clermont PJ, Davis BH, Wang T, Gregg D, Ramaswami P, et al. Aging, progenitor cell exhaustion, and atherosclerosis. Circulation (2003) 108(4):457-63. doi:10.1161/01.CIR.0000082924.75945.48

63. Scheubel RJ, Zorn H, Silber RE, Kuss O, Morawietz H, Holtz J, et al. Agedependent depression in circulating endothelial progenitor cells in patients undergoing coronary artery bypass grafting. J Am Coll Cardiol (2003) 42(12):2073-80. doi:10.1016/j.jacc.2003.07.025

64. Vasa M, Fichtlscherer S, Adler K, Aicher A, Martin H, Zeiher AM, et al. Increase in circulating endothelial progenitor cells by statin therapy in patients with stable coronary artery disease. Circulation (2001) 103(24):2885-90. doi:10.1161/hc2401.092816

65. Britten MB, Abolmaali ND, Assmus B, Lehmann R, Honold J, Schmitt J, et al. Infarct remodeling after intracoronary progenitor cell treatment in patients with acute myocardial infarction (TOPCARE-AMI): mechanistic insights from serial contrast-enhanced magnetic resonance imaging. Circulation (2003) 108(18):2212-8. doi:10.1161/01.CIR.0000095788.78169.AF

66. Ballard VL, Sharma A, Duignan I, Holm JM, Chin A, Choi R, et al. Vascular tenascin-C regulates cardiac endothelial phenotype and neovascularization. FASEB J (2006) 20(6):717-9. doi:10.1096/fj.05-5131fje

67. Mongiat M, Andreuzzi E, Tarticchio G, Paulitti A. Extracellular matrix, a hard player in angiogenesis. Int J Mol Sci (2016) 17(11):1822. doi:10.3390/ijms17111822

68. Eming SA, Hubbell JA. Extracellular matrix in angiogenesis: dynamic structures with translational potential. Exp Dermatol (2011) 20(7):605-13. doi:10.1111/j.1600-0625.2011.01309.x

69. Ashcroft GS, Horan MA, Ferguson MW. The effects of ageing on cutaneous wound healing in mammals. J Anat (1995) 187( Pt 1):1-26.

70. Lemanska-Perek A, Pupek M, Polanska B, Leszek J, Katnik-Prastowska I. Alterations in molecular status of plasma fibronectin associated with aging of normal human individuals. Clin Biochem (2013) 46(9):787-94. doi:10.1016/j. clinbiochem.2013.03.008

71. Visse R, Nagase H. Matrix metalloproteinases and tissue inhibitors of metalloproteinases: structure, function, and biochemistry. Circ Res (2003) 92(8):827-39. doi:10.1161/01.RES.0000070112.80711.3D

72. Reed MJ, Corsa AC, Kudravi SA, McCormick RS, Arthur WT. A deficit in collagenase activity contributes to impaired migration of aged microvascular endothelial cells. J Cell Biochem (2000) 77(1):116-26. doi:10.1002/ (SICI)1097-4644(20000401)77:1<116::AID-JCB12>3.3.CO;2-Z

73. Koike T, Vernon RB, Gooden MD, Sadoun E, Reed MJ. Inhibited angiogenesis in aging: a role for TIMP-2. J Gerontol A Biol Sci Med Sci (2003) 58(9):B798-805. doi:10.1093/gerona/58.9.B798

74. Kang DH, Anderson S, Kim YG, Mazzalli M, Suga S, Jefferson JA, et al. Impaired angiogenesis in the aging kidney: vascular endothelial growth factor and thrombospondin-1 in renal disease. Am J Kidney Dis (2001) 37(3):601-11. doi:10.1053/ajkd.2001.22087

75. Agah A, Kyriakides TR, Letrondo N, Bjorkblom B, Bornstein P. Thrombospondin 2 levels are increased in aged mice: consequences for 
cutaneous wound healing and angiogenesis. Matrix Biol (2004) 22(7):539-47. doi:10.1016/j.matbio.2003.09.004

76. Finkel T, Holbrook NJ. Oxidants, oxidative stress and the biology of ageing. Nature (2000) 408(6809):239-47. doi:10.1038/35041687

77. Minamino T, Miyauchi H, Yoshida T, Ishida Y, Yoshida H, Komuro I. Endothelial cell senescence in human atherosclerosis: role of telomere in endothelial dysfunction. Circulation (2002) 105(13):1541-4. doi:10.1161/01. CIR.0000013836.85741.17

78. Burrig KF. The endothelium of advanced arteriosclerotic plaques in humans. Arterioscler Thromb (1991) 11(6):1678-89. doi:10.1161/01.ATV.11.6.1678

79. Ross R, Wight TN, Strandness E, Thiele B. Human atherosclerosis. I. Cell constitution and characteristics of advanced lesions of the superficial femoral artery. Am J Pathol (1984) 114(1):79-93.

80. Samani NJ, Boultby R, Butler R, Thompson JR, Goodall AH. Telomere shortening in atherosclerosis. Lancet (2001) 358(9280):472-3. doi:10.1016/ S0140-6736(01)05633-1

81. Jeanclos E, Krolewski A, Skurnick J, Kimura M, Aviv H, Warram JH, et al. Shortened telomere length in white blood cells of patients with IDDM. Diabetes (1998) 47(3):482-6. doi:10.2337/diabetes.47.3.482

82. Epel ES, Blackburn EH, Lin J, Dhabhar FS, Adler NE, Morrow JD, et al. Accelerated telomere shortening in response to life stress. Proc Natl Acad Sci U S A (2004) 101(49):17312-5. doi:10.1073/pnas.0407162101

83. Gardner JP, Li S, Srinivasan SR, Chen W, Kimura M, Lu X, et al. Rise in insulin resistance is associated with escalated telomere attrition. Circulation (2005) 111(17):2171-7. doi:10.1161/01.CIR.0000163550.70487.0B

84. Valdes AM, Andrew T, Gardner JP, Kimura M, Oelsner E, Cherkas LF, et al. Obesity, cigarette smoking, and telomere length in women. Lancet (2005) 366(9486):662-4. doi:10.1016/S0140-6736(05)66630-5

85. Demissie S, Levy D, Benjamin EJ, Cupples LA, Gardner JP, Herbert A, et al. Insulin resistance, oxidative stress, hypertension, and leukocyte telomere length in men from the Framingham Heart Study. Aging Cell (2006) 5(4):325-30. doi:10.1111/j.1474-9726.2006.00224.x

86. Epel ES, Lin J, Wilhelm FH, Wolkowitz OM, Cawthon R, Adler NE, et al. Cell aging in relation to stress arousal and cardiovascular disease risk factors. Psychoneuroendocrinology (2006) 31(3):277-87. doi:10.1016/j. psyneuen.2005.08.011

87. Minamino T, Yoshida T, Tateno K, Miyauchi H, Zou Y, Toko H, et al. Ras induces vascular smooth muscle cell senescence and inflammation in human atherosclerosis. Circulation (2003) 108(18):2264-9. doi:10.1161/01. CIR.0000093274.82929.22

88. Coppe JP, Patil CK, Rodier F, Sun Y, Munoz DP, Goldstein J, et al. Senescence-associated secretory phenotypes reveal cell-nonautonomous functions of oncogenic RAS and the p53 tumor suppressor. PLoS Biol (2008) 6(12):2853-68. doi:10.1371/journal.pbio.0060301

89. Keymel S, Kalka C, Rassaf T, Yeghiazarians Y, Kelm M, Heiss C. Impaired endothelial progenitor cell function predicts age-dependent carotid intimal thickening. Basic Res Cardiol (2008) 103(6):582-6. doi:10.1007/ s00395-008-0742-z

90. Lakatta EG, Levy D. Arterial and cardiac aging: major shareholders in cardiovascular disease enterprises: part I: aging arteries: a "set up" for vascular disease. Circulation (2003) 107(1):139-46. doi:10.1161/01.CIR.0000048892. 83521.58

91. Tesauro M, Mauriello A, Rovella V, Annicchiarico-Petruzzelli M, Cardillo C, Melino G, et al. Arterial ageing: from endothelial dysfunction to vascular calcification. J Intern Med (2017) 281(5):471-82. doi:10.1111/joim.12605

92. Libungan B, Karlsson T, Albertsson P, Herlitz J. Elderly patients with myocardial infarction selected for conservative or invasive treatment strategy. Clin Interv Aging (2015) 10:321-7. doi:10.2147/CIA.S74012
93. Zachary I, Morgan RD. Therapeutic angiogenesis for cardiovascular disease: biological context, challenges, prospects. Heart (2011) 97(3):181-9. doi:10.1136/hrt.2009.180414

94. Said SS, Pickering JG, Mequanint K. Advances in growth factor delivery for therapeutic angiogenesis. J Vasc Res (2013) 50(1):35-51. doi:10.1159/ 000345108

95. Kamihata H, Matsubara H, Nishiue T, Fujiyama S, Tsutsumi Y, Ozono R, et al. Implantation of bone marrow mononuclear cells into ischemic myocardium enhances collateral perfusion and regional function via side supply of angioblasts, angiogenic ligands, and cytokines. Circulation (2001) 104(9):1046-52. doi:10.1161/hc3501.093817

96. Tateishi-Yuyama E, Matsubara H, Murohara T, Ikeda U, Shintani S, Masaki H, et al. Therapeutic angiogenesis for patients with limb ischaemia by autologous transplantation of bone-marrow cells: a pilot study and a randomised controlled trial. Lancet (2002) 360(9331):427-35. doi:10.1016/ s0140-6736(02)09670-8

97. Akita S, Akino K, Imaizumi T, Hirano A. A basic fibroblast growth factor improved the quality of skin grafting in burn patients. Burns (2005) 31(7):855-8. doi:10.1016/j.burns.2005.04.008

98. Nakamizo S, Egawa G, Doi H, Natsuaki Y, Miyachi Y, Kabashima K. Topical treatment with basic fibroblast growth factor promotes wound healing and barrier recovery induced by skin abrasion. Skin Pharmacol Physiol (2013) 26(1):22-9. doi:10.1159/000343208

99. Barrientos S, Stojadinovic O, Golinko MS, Brem H, Tomic-Canic M. Growth factors and cytokines in wound healing. Wound Repair Regen (2008) 16(5):585-601. doi:10.1111/j.1524-475X.2008.00410.x

100. Moriya J, Minamino T, Tateno K, Shimizu N, Kuwabara Y, Sato Y, et al. Long-term outcome of therapeutic neovascularization using peripheral blood mononuclear cells for limb ischemia. Circ Cardiovasc Interv (2009) 2(3):245-54. doi:10.1161/CIRCINTERVENTIONS.108.799361

101. Murasawa S, Llevadot J, Silver M, Isner JM, Losordo DW, Asahara T. Constitutive human telomerase reverse transcriptase expression enhances regenerative properties of endothelial progenitor cells. Circulation (2002) 106(9):1133-9. doi:10.1161/01.CIR.0000027584.85865.B4

102. Boccardi V, Barbieri M, Rizzo MR, Marfella R, Esposito A, Marano L, et al. A new pleiotropic effect of statins in elderly: modulation of telomerase activity. FASEB J (2013) 27(9):3879-85. doi:10.1096/fj.13-232066

103. Werner C, Gensch C, Poss J, Haendeler J, Bohm M, Laufs U. Pioglitazone activates aortic telomerase and prevents stress-induced endothelial apoptosis. Atherosclerosis (2011) 216(1):23-34. doi:10.1016/j.atherosclerosis.2011.02.011

104. Yamaza T, Miura Y, Bi Y, Liu Y, Akiyama K, Sonoyama W, et al. Pharmacologic stem cell based intervention as a new approach to osteoporosis treatment in rodents. PLoS One (2008) 3(7):e2615. doi:10.1371/journal.pone.0002615

105. Bayne S, Jones ME, Li H, Liu JP. Potential roles for estrogen regulation of telomerase activity in aging. Ann N Y Acad Sci (2007) 1114:48-55. doi:10.1196/ annals. 1396.023

Conflict of Interest Statement: The authors declare that the research was conducted in the absence of any commercial or financial relationships that could be construed as a potential conflict of interest.

Copyright (๑) 2017 Moriya and Minamino. This is an open-access article distributed under the terms of the Creative Commons Attribution License (CC BY). The use, distribution or reproduction in other forums is permitted, provided the original author(s) or licensor are credited and that the original publication in this journal is cited, in accordance with accepted academic practice. No use, distribution or reproduction is permitted which does not comply with these terms. 